\title{
Zinc Substituted Nickel-cobalt Nano-ferrites via Citrate-gel Auto-combustion Method for High- frequency Applications: Studies on Crystal Structure and Dielectric Properties
}

Original Research

Keywords:

Posted Date: February 11th, 2021

DOI: https://doi.org/10.21203/rs.3.rs-156852/v2

License: (c) (i) This work is licensed under a Creative Commons Attribution 4.0 International License. Read Full License 


\section{Abstract}

The authors have requested that this preprint be withdrawn due to author disagreement.

\section{Full Text}

The authors have withdrawn this preprint from Research Square. 